\title{
Interpretation of Symbols, Veneration and Divine Attributes in Dieng Temple Complex, Central Java
}

Ni Kadek Surpi, ${ }^{+*}$ Ni Nyoman Ayu Nikki Avalokitesvari, '̇ I Made Gami Sandi Untara'̂and I Ketut Sudarsana $^{+}$

\section{Abstract}

This study aims to discuss the divine symbols and attributes used as a medium of worship in the Dieng Plateau. The research was phased in according to Wallace's empirical cycle and was conducted in the Dieng Plateau, Central Java, Indonesia, a spiritual centre in ancient Java. The discovery of the Śiva Triśirah statue in the Dieng Temple Complex reveals new things in the past Hindu Nusantara Theology construction. Several divine symbols and attributes are served as a medium of worship at the Temple Complex in the Dieng Plateau. The concept of Deity in the Dieng Plateau is Śivaistic in character with the worship of Lord Śiva Triśirah, that is, Śiva with three faces and four hands, as the Supreme Deity. However, some divine symbols and attributes also serve as a medium of worship and connected to divinity. In Hinduism, the sacred symbols and attributes of God are inseparable. Divine attributes generally define God. In the discussion of theology, God is described with various excellent attributes. The central divine attributes found are as follows: Omnipotence, Creatorship, Omniscience, Eternity and Omnipresence, Personhood, Goodness/ Perfection, Non-Physicality, Necessary, Existence, Simplicity, Immutability and Impassibility. These divine attributes are depicted in various forms of sacred symbols found in the Dieng Plateau.

Keywords: Dieng; Theology; Śiva Triśirah; Symbols; Divine Attributes; Central Java

\footnotetext{
+ Universitas Hindu Negeri I Gusti Bagus Sugriwa Denpasar, Bali, Indonesia

${ }^{*}$ Corresponding Author, Email: dosen.surpiaryadharma@gmail.com

ì The Hindu Center of Indonesia, Email: ayunikkia@gmail.com

ÎSTAH Negeri MPU Kuturan Singaraja, Email:gamisandi@gmail.com

+ Universitas Hindu Negeri I Gusti Bagus Sugriwa Denpasar, Bali, Indonesia, Email: iketutsudarsana@uhnsugriwa.ac.id (C) 2021 Surpi et al. This is an Open Access article distributed under the terms of the Creative Commons Attribution License (http://creativecommons.org/licenses/by/2.0), which permits unrestricted use, distribution, and reproduction in any medium, provided the original work is properly cited.
} 


\section{Introduction}

This study foregrounds the findings in the form of divine symbols and attributes that became a medium of worship in the Dieng Plateau. These divine symbols and attributes are used as a medium to connect between the human realm and gods. It is also used to train human consciousness as a form of ancient Javanese Hindu religious life. The Dieng Plateau, known as the Land of the Gods, the Land of Heaven (Kahyangan), and the Land beyond the Clouds, is a prominent region in ancient Javanese Hindu civilisation. Dieng Plateau is considered the first and foremost holy point on the islands of Java and Nusantara. Some experts call Dieng the World Axis, the Cosmic Axis, which has many divinity signs (Surpi, 2019). In its long history, Dieng is even considered a central point of Hindu civilisation, where the Rși devoted their lives to knowledge, invoking the welfare of the Hindu Kings at various eras in the Land of Java and Nusantara. One important reason that cannot be ignored regarding Dieng's historical dimension is the ancient site or its temples. The temples in the Dieng Plateau are named after figures in Māhābharata and Javanese puppets. This naming holds a historical significance that both Rāmāyaña and Māhābharata Epics had a profound effect on the life of Nusantara people in the past. Moreover, it is also used as a medium for the spread of Hinduism.

Dieng comes from Sanskrit, namely $D i$, a high place or mountain, and Hyang, which means Kahyangan or heaven. From the combination of these words, it can be interpreted that Dieng is an upper region in the form of mountains where the gods and goddesses reside, which should be an ideal paradise. Comprehensively, Di means a high place or mountain and Hyang, which means ancestral spirit or gods or something believed to be a God, ancestral spirit, even God or Divine Creatures in general. Hyang is also often interpreted as kahyangan, nirvana, or heaven, where the ancestral spirits, gods or goddesses, Gods or Divine creatures live (Sukatno, 2004). Moreover, Dieng can also be traced to the meaning of the Kawi language. The word Di comes from the phrase hadi or adi, which means glorious, gorgeous, beautiful, which contains the definition of all-round, the most, and other excellent qualities. The highest or highest peak, mysterious, transcendent, or everything that means completely perfect or ultimate, and the mystery of the perfection of order and faith. Thus Dieng is also an important place in the cosmology of the Land of Java. In addition,' Dieng's position, which is located right in the middle of the island of Java, makes it has a special place for ancient Javanese spirituality.

The Dieng temple complex is a silent witness to Hinduism's rapid development in Java in the past. The Dieng Temple Complex is an ancient temple, which is believed to have been built during the 7th and 8th Centuries. However, several experts argue that it is even older (Harriyadi, 2020). Some records estimated this complex was still used as a Hindu worship complex during the 14th Century, even to the 19th Century. So this temple complex is thought to be one of the oldest temples in Java. It is estimated that this temple was built by order from the Kings of the Sanjaya Dynasty. The construction of this temple complex is divided into two stages. The first phase includes Arjuna Temple, Semar Temple, Srikandi Temple, and Gatotkaca Temple (Sedyawati et al., 2013). The second stage is a continuation of the first stage. An inscription is written in ancient Javanese dating from $808 A D$, and a statue of Shiva is also discovered in this temple complex. These artefacts are now stored in the National Museum in Jakarta. Interestingly, the temples in the Dieng complex use the names of Māhābharata. This phenomenon shows how Māhäbharata literature greatly influenced the ancient Javanese Hindu concept.

In the Dieng Plateau, initially, there were very many temples and worship shrines. It was also estimated that the Dieng temple originally numbered 400 units, but now only 8 Temple complex remains (Sukatno, 2004). However, the eight temple complexes are adequate to be studied to reconstruct Hindu Theology in Ancient Java and interpret the message left from the past 
to the next generation. Many other fascinating things in Dieng Plateau, such as the existence of Anak Gembel, a child with dreads. Munandar (2016) stated that this phenomenon is a mystical communication along time, through the past, present, and future. Several Hindu rituals are still being held in the Dieng Plateau. For example, the ceremony of salvation shaves the dreads hair of Anak Gembel, the tradition of Malam Satu Suro, or the first night on Suro Month in the Javanese Calendar and "Ruwatan Desa" or a ceremony that held to purify the village. Local people realise that this tradition is a relic of the Hindu tradition, but it must still be carried out as a form of respect for their ancestors.

The study of historical relics, such as historical buildings or temples, is significant to understand the religious situation, including the theological concepts that developed at that time. Ancient Javanese theology is essential to be explored to understand the system of Hindu Nusantara Theology (Surpi, 2020). The most important discovery in the Dieng plateau is the statue of Lord Siva Trisiirah. The statue of Lord Śiva with three faces and four hands is classified as an old Hindu relics in Nusantara. The worship of Siva Triśirah is not much expressed in the history of Hindu civilisation in the archipelago. The statue of Siva Trisirah and the statue of Nandisawahanamurti are considered to be characteristic of Dieng. Likewise, other divine symbols and depictions of divine attributes that were part of Ancient Hindu Theology concepts in the Land of Java were also found in Dieng.

The study begins with a discussion of the research method deployed for this study. Following this, the results are critically discussed in the section 'results and discussion'.

\section{Research Method}

This study is based on qualitative research accomplished by collecting data via observation, interviews, Focus Group Discussion (FGD), and literature studies. Observations were made with sightings in the Dieng Plateau (including surveys of all the temple complexes, historical sites, and the Dieng Kailasa museum), Prambanan Temple Complex, Prambanan Museum, and the Indonesian National Museum in Jakarta. The research process is based on Wallace's empirical cycle (1978). Wallace's empirical cycle is a scientific process developed by Walter $\mathrm{L}$. Wallace in his book The Logic of Science in Sociology (2017). This empirical cycle model describes the relationship of components in social research more clearly and in detail. This cycle explicitly explains social research components' association and is directly relevant to empirical research to achieve our study's research objectives (Wallace, 2017) correctly. Wallace's empirical cycle's scientific process includes 1 . theory; 2 . hypothesis; 3 . observation; and 4. empirical generalisation. The four components of scientific information can be changed from one element to another by one of the methodological features: 1 . the logical deduction, 2. interpretation, the arrangement of instruments, 3. measurement, simplification of information, and parameter estimation, 4. formulation of concepts and propositions, 5 . hypothesis testing, and 6. logical inference (Wallace, 1978). As stated above, the research process of Siva Trisirah's theology was carried out based on Wallace's empirical cycle, which had been adapted for theological research. Here, the study begins with a problem and then looks for the right theory used in this research. After that, through logical deduction, it tries to draw a hypothesis. Following this, observations and generalisations are made followed by variable analysis and correlation to achieve research direction, which is outlined below:

- First, they are classifying the Śiva Trisiirah statues based on their characteristics and each statue's size.

- Second, they are formulating the attributes of each class of Śiva Triśirah statues.

- Third, they are making a comparison of the characteristics between Śiva Triśirah statues in Indonesia with the other iconography of Śiva Triśirah statues founded in India. For example, Tri Mukhi Temple, Amarkantak, Madhya Pradesh; Trisirah found in a sacred Guaiva cave on Elepantha Island, east of Mumbai; and Ellora Caves, which is famous for Kailasa Temple. 
- Fourth, the result of the comparison in the third step is a working hypothesis. A working hypothesis is a hypothesis formulation in such a way that the theoretical concepts used are operational. In this case, the hypothesis used is the working hypothesis. Dieng's statue of Śiva Triśirah is the highest worship medium in its era, a sacred attribute, and has conformity and or deviation to similar statues in India.

- Fifth, the working hypothesis's verification is carried out concerning the next stage, namely, stage six.

- In stage six, data processing and interpretation are carried out following Hindu theology's understanding.

- In the last stage, stage seven, namely drawing conclusions. Data analysis uses Ethnographic Content Analysis (ECA). The research approach was based on the Hindu Theology approach, which has diverse views among other religions. The results of the study are discussed in the following sections.

\section{Results and Discussion}

\section{Dieng Temple Complex and Its Calendar Making in Dieng Plateau}

The Dieng Kailasa Museum data states that the Dieng Temple complex was allegedly founded in the 8th Century (Surpi, 2019). However, other views state that this temple was built long before that century. In his book, Pengantar Sejarah Kebudayaan Indonesia 1, Soekmono (1979) stated that the earliest temples were built in the 'Old Dieng Style' between 650 and 730 AD. Meanwhile, Sukatno (2004), in his book entitled Dieng Poros Dunia, examines several written sources in the form of fibres and their relation to local stories and reckons that the temple's existence is older than what these experts' estimated. Until the 13th Century, Dieng was still a spiritual centre in Java. Located on the caldera at the southern foot of Mount Prahu and the western slopes of Mount Ungaran, Dieng, or DiHyang in old Javanese, means residence of the Gods. The Dieng Plateau is a religious centre marked by numerous temples, built from the mid-7th to the early 13th Century. However, currently there remain only eight stone temples, including the five temples in the temple complex of Arjuna and three other temples located in the vicinity, namely Bima Temple, Temple Davaravati, and Temple Ghatotkaca.

The temple at Dieng was rediscovered in 1814 by a British soldier travelling to the area (Chapman, 2013). He saw a cluster of temples submerged in lake water. In 1956, Van Kinsbergen, a DutchFlemish sculptor interested in photography, arrived in the Dutch East Indies (now Jakarta) in 1851 (Sedyawati et al., 2013). He led the effort to drain the lake where the temple was discovered. He took the first archaeological and cultural photographs in Java during the Dutch East Indies period in the 19th Century, working under the Batavia Society of Arts and Sciences. Their main interests were in archaeological research and conservation (Surpi, 2019). The cleaning effort was continued by the Dutch East Indies government in 1864, followed by recording and shooting by Van Kinsbergen (Sedyawati et al., 2013).

The temples in the Dieng plateau are the centre of pilgrimage (Figure 1). A place located in the foothills around the Lake of Telaga Warna were the ascetics settled and made a small meditation cave. Experts believe that the Dieng Plateau may have been a site of ancestor worship in ancient times, where most of them think that the mountain is home to the gods. Dieng is called a holy mountain in an inscription that originated from the 919th Century AD. In the inscription, Dieng is referred to as the city of priests. Its location can be accessed via stairs that lead from Pekalongan plain to the north and Bagelen to the south. A ladder made of igneous rock was found in these two areas between 1860 and 1870 (Sedyawati et al., 2013). 


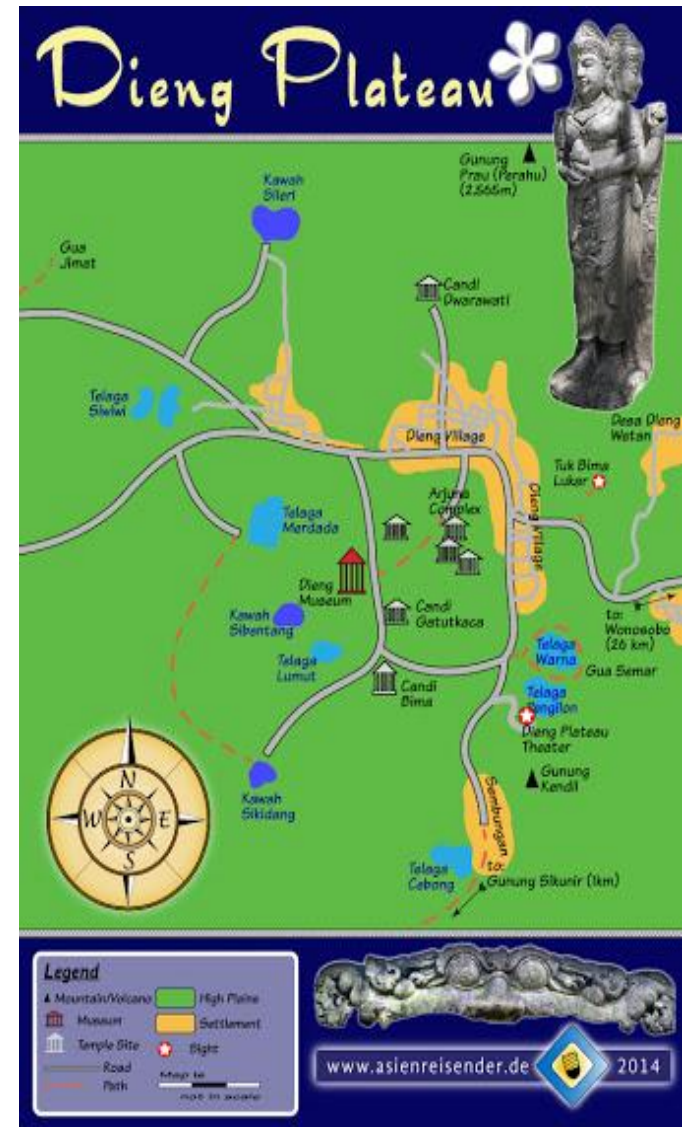

Figure 1: The Map of Dieng Plateau

Source: Asienreisender, 2014

(http://www.asienreisender.de/die

ng.html)

Based on previous research, the Dieng Plateau, used as a place of worship for centuries, was left abandoned and forgotten due to various factors, such as natural disaster and religious changes in the community around Dieng (Harriyadi, 2020). This area is inhabited again around 1830, and after that, many remains of the temple were excavated. Evidence that says Dieng, a hub of around 400 temples, was obtained by discovering inscriptions dating from the 9th to the 13th Centuries (Sukatno, 2004). At present, the Dieng plateau is an agricultural centre with terraced agricultural land along valleys and foothills. Farmers reclaimed most of the land in the 19th Century and transported the remaining majority of the stones that make up the temple for other buildings. Some Dutch sources claim that the temple stones which have been damaged have been used to make the road base (Sukatno, 2004). Meanwhile, the remaining eight temples are given character names in the Javanese version of the Mahābhārata.

Soekmono (1979) argued that the earliest temples were built in the 'Old Dieng Style' between 650 and 730 AD. Canggal temple, located near Borobudur on Mount Wukir (Mount Wukir), is the earliest temple associated with the inscription dated $732 \mathrm{AD}$; however, only its foundation survives. So the temple at Dieng is the earliest stone monument available for further study. Soekmono (1979) also believed that Dieng temples' construction had been completed before the Canggal temple was built. Temples classified using the old Dieng style include Arjuna temple, Semar temple, Srikandi temple, and Ghatotkaca temple. The second stage of building the new Dieng style was between $730 \mathrm{AD}$ and 800 AD. Temples classified into the new Dieng style include Puntadeva 
temple, Sembadra temple, and Bima temple. Gedong Songo temple is the closest dating period to the second phase of the Dieng temple building date. Meanwhile, the Badut temple was the only temple made in this period in East Java.

The temples that still exist are scattered in four different locations. The most preserved / reconstructed site is widely known as the Arjuna Group (Figure 2). It contains five extant temples and several others, occupying a flat valley in the Plateau's centre, near Dieng's current village. The closest temple site is on the southern edge of the valley, the Ghatotkaca temple site, a temple that still exists accompanied by the remains of five other temples. At the northern edge of the valley is the Davaravati temple, again a single temple with the remains of three different temples. Finally, at the foot of the Highlands' southern side is the Bima Temple, which appears to be a single building. While each of the eight temples left in Dieng is the cella, small stones with a single interior space represent various approaches to building type and altar of worship.

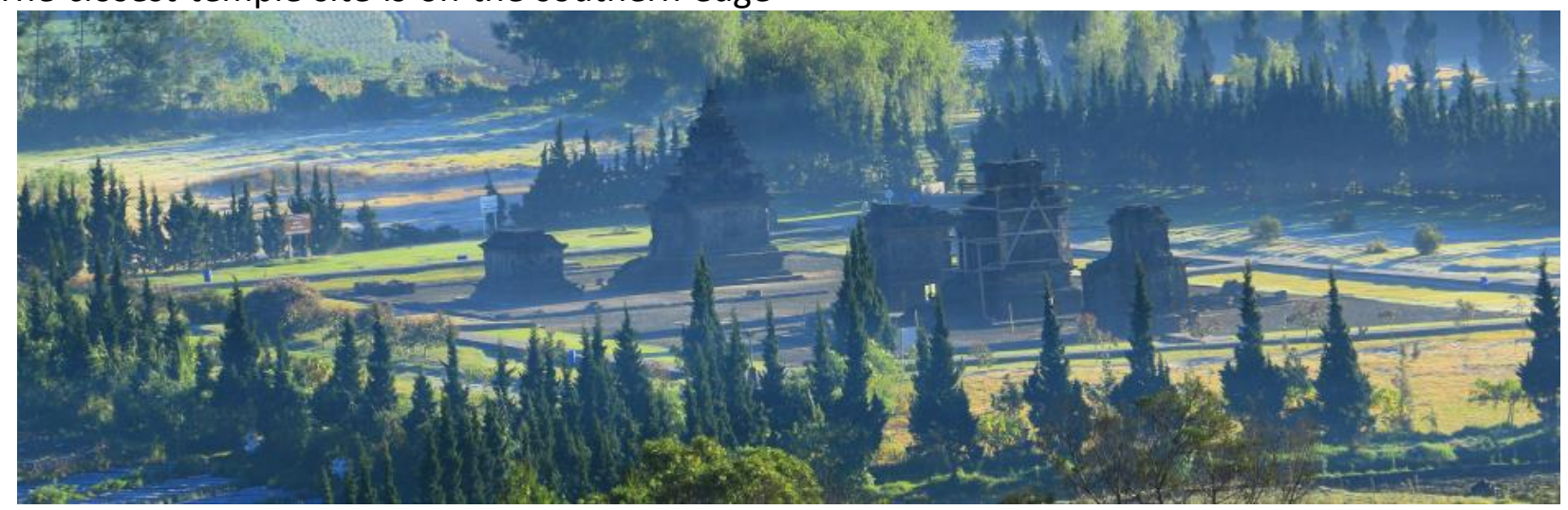

Figure 2: Arjuna Temple Complex

Source: https://diengplateau.com/

\section{The Veneration of Symbol and Divine Attributes in Dieng Temple Complex}

Hindu religious systems cannot be separated from divine symbols and attributes because it is related to the Hindu theology's typology. The typology allows the community to build a complex of worship and its essential part of divine attributes. Donder et al. (2020) asserted that in Saguna Brahman Hindu Theology's typology, God has a form of Devas, incarnations, or saints who teach the truth to humans. The divine symbols or forms emerge from this typology and are used as a worship medium by the public. The divine symbols and attributes found in the Dieng temple complex include the following:

\section{Śiva Triśirah}

Śiva is one of the Supreme Devas in Hindu theology that Śivaistik characterises. Śiva Triśirah is a fascinating and distinctive statue found on the Dieng Plateau. The Siva statue, which is now housed in the Dieng Kailasa
Museum, has three heads, so it is called Tri Sirah or Trimukha. Śiva Trisiirah is considered to have unique features in Dieng considering the discovery of the statue of Śiva Triśirah is quite rare in Indonesia. Furthermore, this statue is thought to be an ancient statue in the worship of Śiva. There are two statues of Śiva Triśirah of different sizes at the Dieng Kailasa Museum. The prominent Śiva Triśirah statue, having a large scale, is accompanied by three faces in different directions and four hands, as shown in Figure 3.

The Śiva Triśirah statue is massive, sitting elegantly in the lotus (padmāsana) position, with the right foot above the left foot. According to ancient yoga knowledge, the right hand is above his left hand in a Dhyana Mudra stance in the front hands. This gesture is a form of meditation in ancient Hinduism and is also used in Buddhist and Jain traditions. Śiva is known as a God who always remains in a meditative position. Therefore, His statue is commonly depicted in a meditating posture. The Śiva's body statue appears in an upright position with eyes that 
appear closed and calm. Although it is not maintained as the procedure for treating statues in Hindu temples in hundreds of years, this Śiva Triśirah still shows His prabava as an incredible ancient statue. In addition to this Śiva Triśirah statue, there is also a smaller statue but a more fragile/weathered condition. The two front hands appear to be incomplete, and the front and rear of the left face are time-worn.

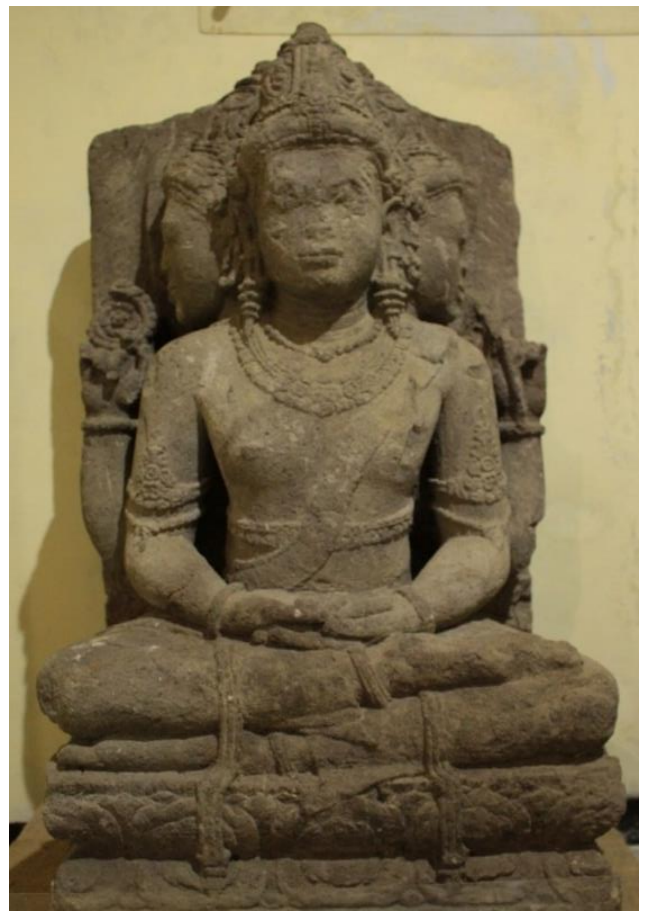

Figure 3 : Śiva Triśirah Statue Dieng in Dieng Kailasa Museum, Central Java Source: Researchers' Documentation in Dieng Kailasa Museum 2019

In Hindu iconography, Śiva has many forms, including Mahesa Mūrti, whose form is depicted as having one or three heads, having a third eye, with a headdress in the form of jatamakuta (Rao, 1968). Apart from Mahesa Mūrti, Śiva Triśirah can also be described as an embodiment of Sadaśiva Mūrti. According to the Uttara Kamikagama Book, Sadaśiva Mūrti can be characterised as having three to five heads and ten hands. When depicted as having ten heads, the five heads are the embodiment of Pancabrahma, namely Sadyojata, Tatpurusa, Vamadeva, Aghora, and Sadaśiva (Isana). All of them wearing jatamakuta. Sadaśiva Mūrti generally carries some laksana such as sula, sakti, katvanga, and bhujanga, with his hands in Abhaya hasta prasadamudra postures. Sadaśiva is sometimes depicted as having four heads, where the head's position is adjusted to the compass's direction. Only three are highlighted between these four heads. The faces expressions of two santa and one ugra (Rao, 1968). Similarly, Maulana (2002) stated that in Indonesia, especially Java, Śiva Triśirah is depicted as having a three-headed face with two santa's facial expressions and one ugra. He is described as having four arms. Each is carrying one of the laksana (attributes), such as camara (a fan made of peacock feathers), aksamala (prayer beads), pustaka (a book made of palm leaves), and nilotpala (blue lotus buds), in the posture of Yogamudra, varada, or vyakhyanahasta. The Siva Triśirah found in Dieng is depicted sitting in the Yogamudra pose.

Śiva is a statue commonly found in various places of worship since ancient times in India and Indonesia. Referring to different research results, in both Indonesia and India, Śiva, as the supreme deity, is known for its five aspects. These five aspects are called pancamuka, which consists of Sadyojata, Vamadeva, Aghora, Tatpurusa, and Isana. Śiva is also known for its nine-aspect group consisting of Śiva, Isvara, Rudra, Brahma, Mahesvara, or Mahesa Mūrti, Mahadeva, Sankara, Vișnu, and Sambhu (Sedyawati, 1979). Seemingly, Maulana ( 2002) 
argued about the existence of Siva Triśirah. First, Maulana (2002) argued Śiva Triśirah as the embodiment of Śiva Tri Mūrti (a god associated with creation, preservation, and demolition). Second, Śiva Triśirah as the embodiment of Sadaśiva Mūrti. In Uttara Kamikagama, the iconographic features of Sadaśiva Mūrti are depicted as having five heads and ten hands. The five heads are aspects of the manifestation of Pancabrahma. Namely Sadyojata (this face of Śiva will give both happiness and sadness to all creatures), Tatpurusa (it represents the structure of soul), Vamedeva (this face of Śiva has special powers to heal both mentally and physically of any creature), Aghora (this face of Śiva is Buddhi rūpa or intellect), and Sadaśiva (Isana) (represents the Citta Śaktī of Śiva, represents space), all wearing jatamakuta (crown). Sadaśiva Mūrti is generally depicted with laksana (attributes) in the form of sula, shakti, khatvanga, and bhujangga, with the Abhaya, Hasta, and Prasada's hand-posture (Rao, 1914). Besides being five-headed, Sadaśivamūrti can also be described as being four-headed. The head position is adjusted to the compass's direction, and among these four heads, only three are highlighted. The facial expressions depicted - two santa and one ugra (Sharma, 1976). The third form is Śiva Trisiirah, as the embodiment of Mahesamūrti. Mahesamūrti is described as having three heads, with facial expressions of two santa and one ugra (Rao, 1968). The left head depicts santa's facial expression as the face of Aghora Mürti, the middle head, which represents the ugra facial expression. Indeed Gopitha Rao's (1968) opinion is endorsed by Kramrisch (1976), which argues that the left head depicts Aghora-Bhairawa. The middle head depicts Śiva Mahadeva, a manifestation of Śiva as Tatpurusa, and the right head depicts Vamadeva-Uma, the sakti of Śiva.

Taking the views of scholars - Rao (1968) and Kramrisch (1954), Maulana (2002) buttresses Śiva as the embodiment of Mahesamūrti. This idea is evidenced by the forms of Siva Triśirah statues in Java, which are generally depicted as having three heads with two facial expressions of santa and one ugra. Śiva is portrayed sitting in the posture of yogasana or paryankasana on the padmasana. All three heads are wearing jatamakuta. Siva Triśirah is depicted as having four arms, both front hands, in the posture of yogamudra or varadahasta and vyakyanahasta. The two backhands carry camara (a fan made of peacock feathers), aksamala (prayer beads), Pustaka (a book made of palm leaves), and nilotpala (blue lotus buds) or the Padma. The middle head with the ugra facial expression is the embodiment of Sadyojata. The left head with santa's facial expression is the embodiment of Aghora Mürti. The right head with the santa's facial expression that Gopinatha Rao has not expressed is thought to be the head of Siva Mahadeva, as expected (Kramrisch, 1954). Likewise, the three jatamakuta (crown) of Śiva Triśirah decorations do not show three strands of gems like the statue of Śiva Triśirah in India, but rather a rosette and flower decoration and one or two strands of jewels.

One of the revered manifestations is Śiva Triśira or in Old Javanese Triśirah (three heads). Śiva, with three faces embodiment, otherwise known as Tri Mukhi Trishira, is the embodiment of Śiva that is classified as rare. In India, Śiva with three faces is found in Tri Mukhi Temple, Amarkantak, Madhya Pradesh India, a famous ancient holy temple. Furthermore, a large statue of Trisirah is located in the sacred cave of Siva on Elepantha Island, east of Mumbai. This monolithic temple is a UNESCO World Heritage site. The statue of Śiva Triśirah is also found in Ellora caves, Aurangabad district of Maharashtra, India, famous for Kailasa temple. This site is a very ancient temple complex of Śiva, which also belongs to a world heritage site.

We believe that Śiva Triśirah is not a combination or manifestation of Tri Mūrti, but represents the three forces of creation, preservation, and demolition or full power in one embodiment of Śiva. Besides, Śiva represents three manifestations of time, namely the past, present, and future. Representation of the object of eternal worship and His transcendence of three natural influences, Sattva, Rajas, and Tamas. Thus, these three faces represent a supreme power, Supreme Deity. Sadaśiva or Parabrahman 
himself is worshipped at all times, in all circumstances, beyond time. These three faces are the representation of all the highest power, strength, and omnipotence of God.

\section{Nandisavahanamūrti}

Another fascinating statue found in the Dieng Temple Complex is Nandisavahanamūrti, Nandi, the sacred bull, carrying the God Siva on his shoulder. Nandi is depicted sitting in an asana (sitting in meditation pose), with both hands supporting Śiva's legs. Śiva seemed to be sitting upright and calm (Figure 4). However, unfortunately, this statue is not intact. The head and neck of Siva no longer exist. Besides, part of his hands is imperfect.

In Hindu mythology, Nandi is a vehicle for Lord Siva. Nandi is usually depicted in the form of a sacred bull in a crouch position. However,
Nandi's statue in the Dieng temple complex is portrayed as a bull-headed human, in a crosslegged sitting position, and holding the Lord Śiva on his shoulder. The way Nandi carried Lord Śiva was also unique, like someone who is riding a horse. Such depictions of statues, until now, have only been found in the Dieng Plateau region (Asianto, 2015).

This statue seemed to leave a message that a devotee must diligently meditate by holding Śiva, his idol god, on his shoulders. The whole body supports Śiva. Theologically, it can be interpreted that in meditation for a worshiper, the Revered God is not far away but is upheld on the shoulders in the form of divine awareness. This interpretation is what distinguishes the typology of Hindu theology from other religions. Hindus consider God very close. Even the spirit entity must be His servant by upholding Thee.

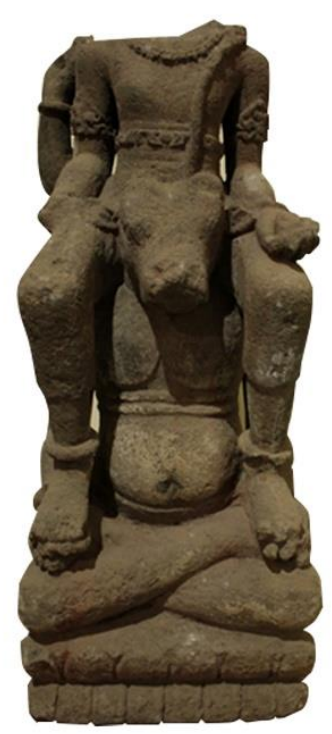

Figure 4: Statue of Nandisavahanamūrti Source: Researchers' Documentation, 2019

\section{Śiva Mahadeva, Parvati and Linga}

In Dieng Plateau, besides the Śiva Trisiirah statue, many other statues of Śiva, both large and small, are found either in a sitting position in meditation or a standing position. A large statue of Siva sitting in a meditation position is now placed in the Dieng Museum. The Siva statue is in a damaged condition. The head is lost; some parts of his body are also damaged. Śiva seemed to be sitting in a meditative position on a lotus flower. Titib (2003) argues that the word Śiva means the one who gives good luck (karahayuan), kind, friendly, forgiving, pleasing, giving much hope, being calm, happy, and so forth. In moving the law of omnipotence Sang Hyang Śiva is supported by His Śakti, Durgā or Pārvati. The statue of Siva Mahadeva, Parvati, and Linga, are shown in Figure 5.

As already stated, besides the large statue, there is also a smaller statue of Siva in the standing 
position. The statue is still intact, believed to be the statue of Siva because of the characteristics of the crown of braided hair (jatamakuta), kalasa (jug), trisula (Lord Shiva's spear with three points), and camara (a fan made of peacock feathers). Information about the certainty of the temple site where the discovery of this statue is still unfunded. It is because, in ancient times, temples were scattered in this Plateau with extraordinary natural scenery.
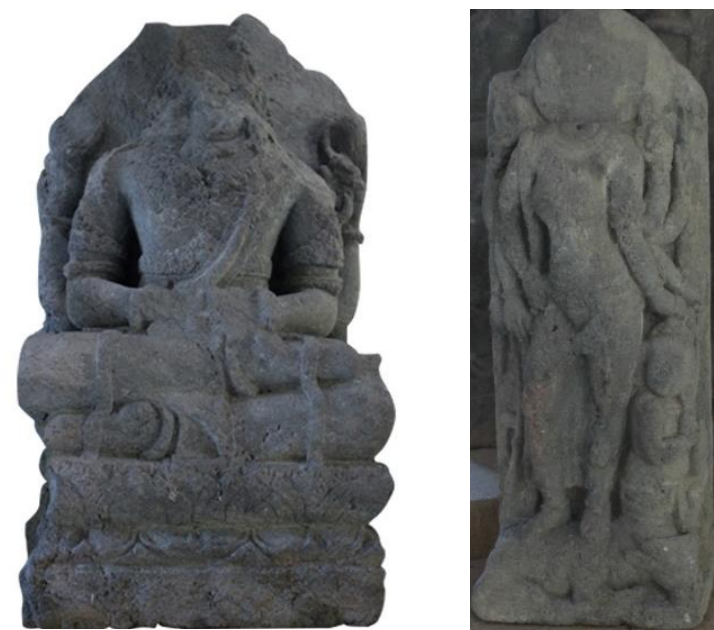

Figure 5: Statue of Śiva Mahadeva, Parvati, and Linga

Source: Researchers' documentation, 2019

\section{Durgā Mahișāsuramardhinī}

In the Dieng temple complex, the statue of Durgā Mahișāsuramardhini was also found (Figure 6). This discovery became an indication of the worship of feminine aspects (Śakti) at Dieng. This Durgā statue has eight hands. Each of the statue's arms holds a weapon and stands on the bull of Mahisasura, which she defeated. Just like most of the other statues, the condition of this statue is in a damaged condition. Part of the face is not perfect; some of her legs and hands have been broken or even lost.

The Vedic literature, mainly in the epics and purānas, notes popular myths and legends. One of them is about Siva and Durgā. Where the Goddess Durgā is described as the Śakti of God Siva. Mother Goddess Durgā has various forms for different purposes. One that stands out is the Buffalo-trampler (Mahișā Mardhinī), highly glorified and worshipped in Devī Māhātmya, which is part of the Mārkaṇdeya Purāna (Aiyar,
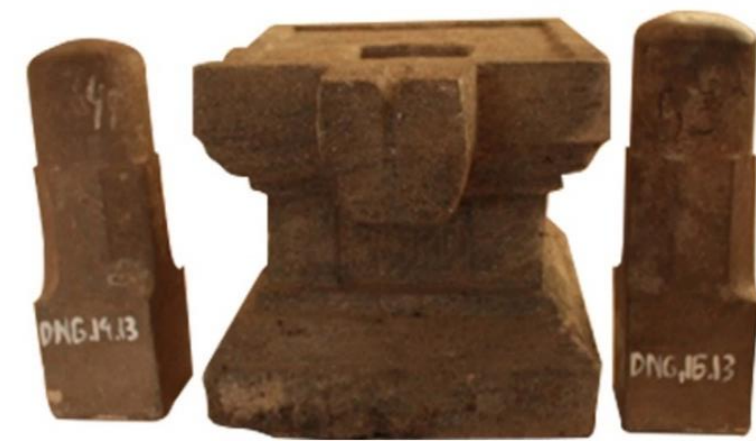

In the Dieng Plateau, as the oldest holy point on the island of Java, also found worship media in the form of linga. Linga is the medium of worship of Śiva, also known as Śivalinga, a significant symbol, which is usually complemented by yoni. Another unique thing is the discovery of a medium-sized Śiva-Parvati statue. This statue is impressive because it is very rarely found in Indonesia, Śiva-Parvati in one stone statue. ŚivaParvati is in a standing position, with some parts, especially the face, in a damaged condition.

1997). Indonesia, which is part of the great Vedic civilisation, has traces of Devi worship. The worship of Durgā Devi in the form of Durgā Mahișāsuramardhini is one of the most famous. Also, the evidence of the worship for Śri Devi, the Śakti of Śri Visnuu were found. Goddesses Śrī Lakșmi is worshipped as the Goddess of Prosperity.

\section{Ganesha}

In the Hindu tradition, Ganesha is the first deity to be worshipped first in every worship. Also, Lord Ganesha is worshipped in the first temple. Following the concept of Hindu theology, Ganesha is a God who destroys all hurdles and obstacles and confer Sidhi and Budhi (power and intellect). Besides, Ganesha was the earliest deity worshipped before worshipping Śiva, who was His father.

The characters in Māhābharata and even Hindu deities evolved and were earthed in Nusantara in a wayang character. In the Purwa puppet, 
Dewa Ganesha, called Batara Gana (Figure 7), is the name of an elephant-headed deity who is the son of Batara Guru and Umaranti Batari. He has another name that is Ganapati, Ganesha, and Wigneswara. When getting a human head to

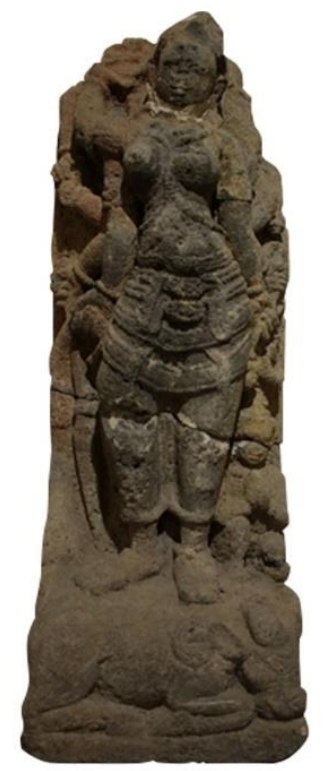

Figure 6: Statue of Durgā Mahișāsuramardhinī

Source: Researchers' documentation, 2019

Batara Gana, or often called Sang Hyang Ganesha, is a God who mastered science. For this reason, Ganesha became a symbol of institutional knowledge in Indonesia. Batara Gana's form is unique; it has a large body, while its head is like an elephant's head. Batara Gana lives in the Glugutinatar Kahyangan, a magnificent palace in the Jonggringsaloka region. The castle itself is shaped in a silver sheen that is colourful by the sun's rays.

When heaven (Kahyangan) was attacked by a giant army led by King Nilaudraka from Gluguginantar state, who wanted the seven most beautiful angels in heaven, the army of the devatas were unable to match it. Parwati Devi, who was pregnant, had to evacuate with other angles to avoid the tantrum of King Nilaudraka, who devastated the entire heaven, so Batara Indra had to fight it with his white elephant.

Unexpectedly, Parwati Devi, who witnessed the course of the battle with a face full of fear, had fallen. Her womb collided so that later, she gave replace the elephant head, Batara Gana also changed its name to Batara Mahadewa. It is said that because Umayi Devi turned into Batara Durga, Batara Guru then married Parwati Devi, and from that marriage, Ganesha was born.

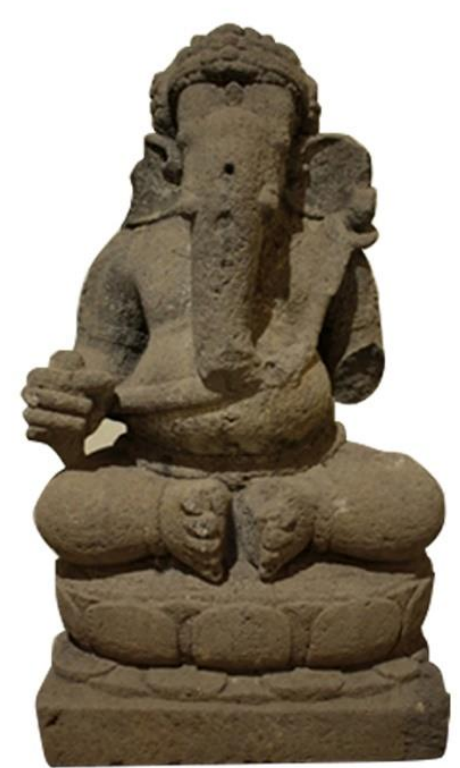

Figure 7: Statue of Ganesha birth to a baby devata, but with a giant face, an elephant's head. The miraculous baby was then treated with gege water, known as Tirtha Amerta Kamandalu, by the Batara Guru. This water is causing the baby to overgrow to become large. After that, the miraculous baby boy was later appointed as the devatas' champion to rival King Nilaudraka and finally succeeded in killing the heavenly intruders' leader. After that, Batara Gana grew up to be a smart kid and very smart in science.

\section{Viṣnu-Śakti and Hari Hara}

In the Dieng temple complex, the statue Vișnu and Śakti are also found. This statue is unique because of its unusual posture. This statue seems to hug each other. Vișnu is depicted in half crouched position, while Śakti is in a kneeling posture. Śakti leaned His head on Vișnu in a position to hug Vișnu (Figure 8). Vișnu's left hand appears to be around His waist. However, unfortunately, this unique statue is in a condition that is not intact, so it seems not too 
clear. This statue can be a message for grhasta (householders), how Vișnu the Preserver and Laksmi must work together to realise life on earth that is good and prosperous. This statue is classified as very unique, considering that it is infrequent for Vișnu and His Śakti to embrace each other. The Dieng Kailasa Museum's explanation, allegedly, is ancient, so it is already in worn condition. The attributes used or brought to this statue is not clear.

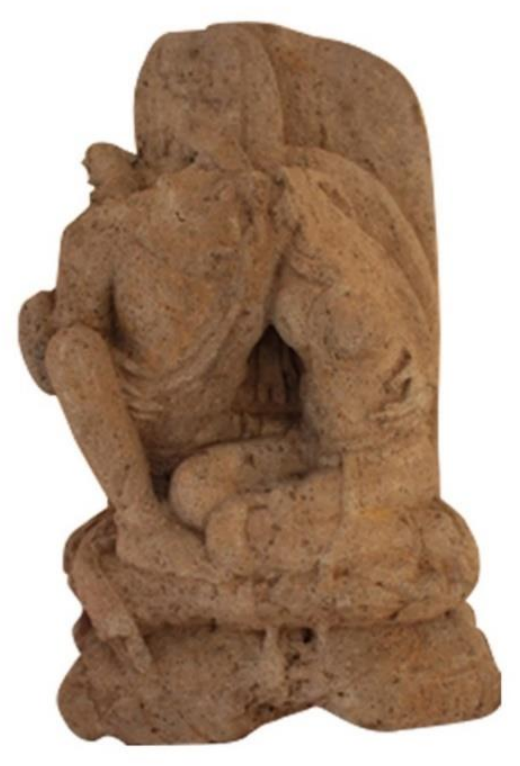

Figure 8: Statue of Vișnu - Śakti and Hari Hara Source: Researchers' documentation, 2019

\section{Agastya Guru}

The Agastya statue is also found in the Dieng Plateau. Like the Agastya statue in Indonesia, this statue is described as having a beard and a protruding belly with his hand holding a pot of tirta kamandalu (holy water of eternity) (figure 9). When viewed from the meaning of theology, Agastya brought tirta kamandalu as a representation of his task, carrying a tirta (holy water) of eternity. This representation can have a profound sense: to bring spiritual, sacred knowledge capable of giving humans immortality. Agastya has been the Adi Guru, who has guided the Nusantara people since ancient times, today, and in the future, through His Holy teachings.

Poerbatjaraka (1992), in his book entitled: Agastya di Nusantara, tells the arrival of Agastya
Another statue is the statue of Hari Hara (Figure 8). This statue depicts Śiva and Vișnu in one character. This statue is worshipped by Hindus who worship Śiva (Śivaistik), as well as Vișnu worshippers, known as Vaisnava. Various literary sources and inscriptions tell several names of these types of images, such as HariSankara, Śiva-Kesava, Sankara-Narayana, Murariswara-Ardhasauriswara. The Śiva-Vișnu statue found in Dieng is known as Hari-Hara.

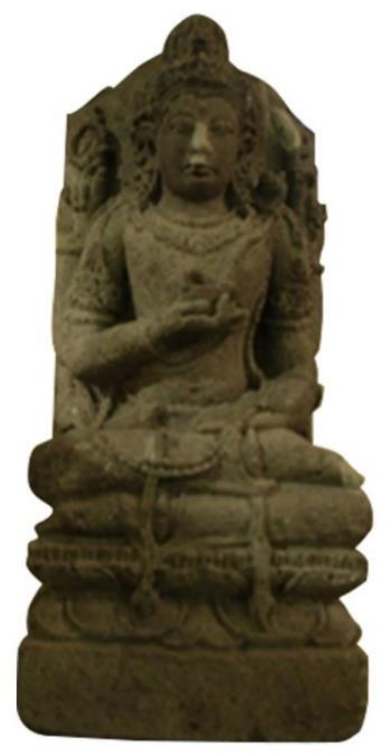

in Java coherently. The Maha Rși appears in sacred tales, and he hiddenly appeared in the Canggal inscription. The holy person who later appeared in the statues of bearded older men, with a fat belly and holding a jug and aksamala (prayer beads), was an inseparable part of the central figures who occupied the niches of Śiva temple in many places (Poerbatjaraka, 1992).

The teacher's role is indeed significant in achieving enlightenment and awareness. Teacher worship is a prevalent tradition because the teacher is considered as a guide to attain realisation. The teacher is seen as a means of learning divinity and attaining supreme awareness. Agastya, in various texts, is known as Bhațțāra-Guru. Agastya Parwa (Sura, 2002) stated that Bhagawan Agastya was very famous in Sanskrit literature as a Bhagavan who spread Hinduism to South India until he reached 
Nusantara. He was a wandering Bhagavan who did not return home. According to Agastya Parwa, Bhagawan Agastya was not merely a legendary figure, but he was considered a great guiding teacher. Thus, it can be proven by the Agastya statue's position in the Prambanan temple, which is in one temple together with the other Śiva s family.

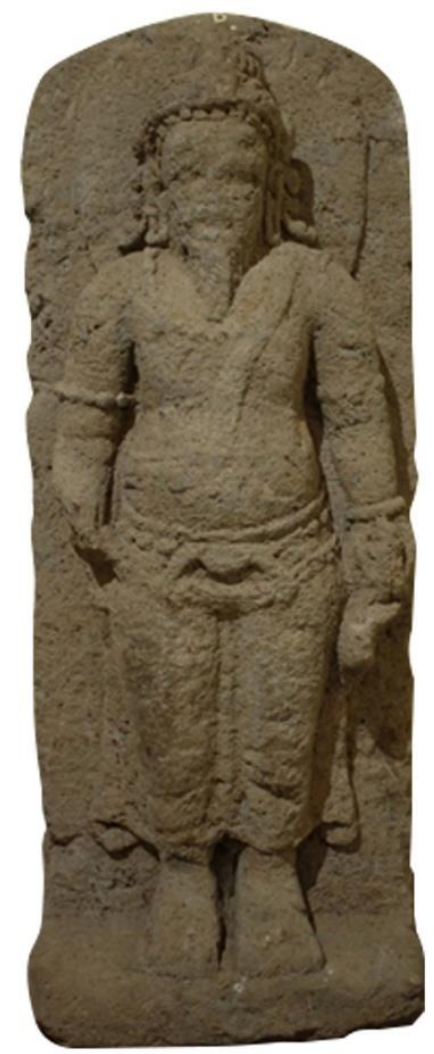

Figure 9: Statue of Agastya Guru

Source: Researchers' documentation, 2019

\section{The Wheel of Dharma}

The Wheel of Dharma artefact is fascinating in Dieng Plateau, which is now stored in the Indonesian National Museum. The Wheel of Dharma looks very simple but holds a million meanings (figure 10). Not yet found an explanation from experts about the discovery of the Wheel of Dharma. However, as is customary in temples, ashrams, or Dharmasala, the possibility of the Wheel of Dharma is a meaningful decoration and message on a wall or fence. The Wheel of Dharma is a common thing related to the Knights' three obligations as taught in Māhābharata. The Māhābharata teachings are deeply rooted until today in the Dieng Plateau.

The relics that exist on Dieng are usually labelled after the names that related to the world of wayang (the epic Māhābharata, and Rāmāyaṇa) which are in Nusantara, especially Java, later known as Wayang Purwa. However, according to Sukatno, the naming of particular places, objects, and areas in Dieng related to the world of wayang or shadow puppets turned out to have nothing to do with the buildings' function.

The name is a new name (Renville estimates since the beginning of the 19th Century AD). However, according to hermeneutics, the name is associated with several text premises. Furthermore, it also represents a symbolic map, which is related to the world of meaning (rational thinking) and the world of feelings (esoteric) (Sukatno, 2004). This perception is still challenging and remains to be verified. Still, it is contrary to the local communities belief, which states that the naming has occurred since ancient times and is inherited from generation to generation. 


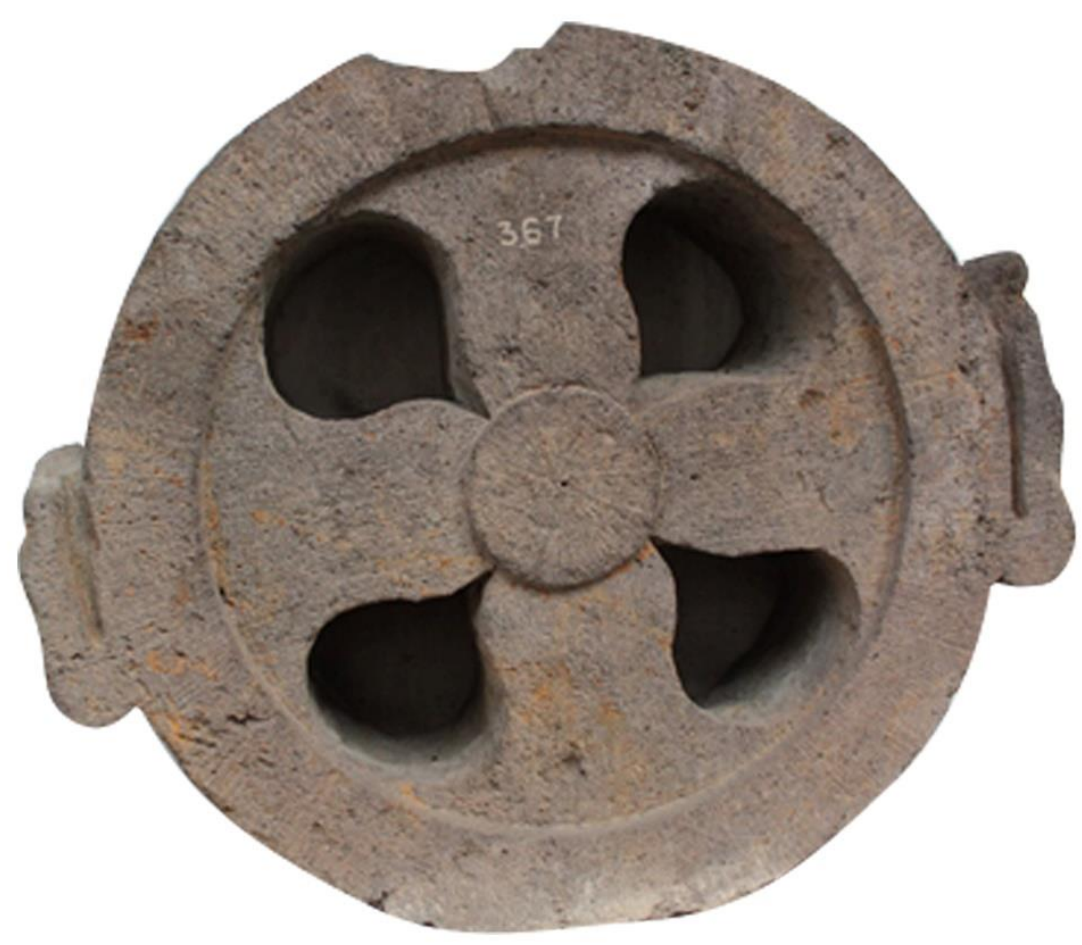

Figure 10: The Wheel of Dharma Statue Source: Researchers' documentation, 2019

\section{The Interpretation of Divine Attributes Founded in Dieng Plateau}

In Hinduism, God's divine symbols and attributes cannot be separated. The divine attributes generally define God. In discussing theology, God is portrayed with a variety of fascinating attributes. For instance, (Everitt, 2010) stated that the main divine attributes include: omnipotence, creatorship, omniscience, eternity and omnipresence, personhood, goodness/ perfection, non-physicality, necessary, existence, simplicity, immutability, and impassibility. In Western theism, these divine attributes are widely discussed. Even it become points that must be solved both theologically and philosophically. There is no theological doctrine that is more general than divine attributes (Holmes, 2009). Divine attributes are frequently debated in the discussion of the theology of religions.

Scholars like Rosenkrantz \& Wierenga (1991) provide precise, subtle, and exciting defences of the following controversial claims:
- There are things that even an omnipotent agent cannot do, but omnipotence can be adequately defined in a manner consonant with this.

- Omniscience is knowledge of all truths, including truths involving the haecceities of persons and times and truths about what a person would freely do (in the libertarian sense) in various circumstances.

- Divine foreknowledge of human actions is compatible with human freedom.

- Divine eternity, timelessness, and immutability are compatible with divine omniscience and action.

- God is impeccable and essentially good.

- The divine command theory of morality is viable (Rosenkrantz \& Wierenga, 1991). These points are also essential topics in Hindu divinity philosophy. In this context, (Surpi et al., 2020) states that the divine concept is translated and understood in various ways in Hinduism. This divinity is depicted in various sacred 
symbols to be worshipped as concrete manifestations to generate sense

Omnipotence is the most talked-about divine attribute. Nevertheless, in the context of Hindu theology, the translation is different. Omnipotence is translated that God can manifest in various forms and even incarnate because of unlimited abilities and power. The aim is to teach kindness and encourage humanity to realise its higher divinity and purpose. In this context, the ancient Javanese people in Dieng also translated divine attributes into various omnipotence forms. Śiva Triśirah is a manifestation of God the almighty that encompasses omnipotence, creatorship, omniscience, eternity and omnipresence, personhood, goodness/perfection, existence. Three faces also describe three past, present, and future times. Non-physicality in Hinduism is called Acintya. Nevertheless, even though it is unthinkable, indescribable, humans still make their form even though it will be drawn by transcending duality-not humans, not animals, not men, not women.

Dieng's local community considers God as a supreme being who deserves to be worshipped. Thus, the divine attributes attached to him are described in various ways. These descriptions would lead to high admiration, love, and spiritual emotions for the worshiper. The divine attribute presents some interesting philosophical problems. Attributes and symbols provide new meaning in the world of theology. In the Dieng Plateau, we find symbols and divine attributes worthy of worship both in form and spirit and knowledge. The symbols that have been found express various sacred attributes imposed on him so that he deserves to be worshipped, honoured, and believed in providing a good over human life. Taking the arguments from the research Barrett (1998), cognitive perspectives also play an essential role in describing God's divine attributes. Humans try to understand through

the cognitive function to reach the divine aspect. The concept of divine attributes found in Dieng is more appropriate with divinity from a historical perspective. Many primitive religions are hartartism. That is, they imply that every type of object has supernatural powers. It was common in ancient times to believe in the plurality of the gods. There was no clear consensus about whether the gods were material or spiritual in nature (Holmes, 2009). However, in discussing God's attributes, it is emphasised whether God cannot be spoken in human language and cannot be known by the human mind. These two things are still an ongoing discussion. Therefore, the effort to find the right words to describe the debate about God's attributes is a task that still needs to be carried out.

\section{Conclusion}

The Dieng Plateau is widely identified as a spiritual centre and gathering place for ancient saints in the Land of Java. Therefore, the worship of various divine symbols and attributes is founded in this place. Various sacred forms are found in Dieng, namely Śiva Triśirah, Nandisavahanamūrti, Śiva Mahadeva, Parvati, and Linga Durgā Mahișāsuramardhinī, Ganesha, Vișṇu Śakti, Hari-Hara, Agastya Guru and The Dharma Wheel Artifacts. This divine attribute is manifested as a means of worship and to induce adoration, respect, and love in devotees' hearts. In Hinduism, God's symbols and divine attributes cannot be separated and exist simultaneously in physical and non-physical forms in the form of sense and understanding.

The highest medium of worship, namely Śiva Triśirah, that is, Śiva with three faces, is Supreme Lord representing the three powers of creation, maintenance and dissolution or full power in one manifestation. Moreover, Śiva represents the three-time, namely past, present and future or as an object of eternal worship. It is a representation of all the supreme power and omnipotence of God. God's divine attributes depicted in the Dieng temple complex relate to Natural Theology discussions. Namely omnipotence, creatorship, omniscience, eternity and omnipresence, personhood, goodness/ perfection, non-physicality, necessary, existence, simplicity, immutability and impassibility. This attribute is reflected in various sacred symbols found in the temple complex on the Dieng Plateau. 
Hindu researchers and scholars should do more scientific research on Hindu theology in Nusantara. So far, the number of writings found is minimal. The scientific standards of theological research must also be studied carefully. Also, Hindus of the world should create more intellectuals and stimulate books writings regarding the development of philosophy and theology. Furthermore, the Hindu concepts that Western scientists have misinterpreted should be comprehensively improved.

\section{References}

Aiyar, I. S. (1997). Durgā Mahișāsuramardhinī A Dynamic Myth of Goddess. Gyan Publishing House.

Asianto, D. R. (2015). Karakteristik Arca Pada Kompleks Percandian Dieng. Universitas Gadjah Mada.

Barrett, J. L. (1998). Cognitive Constraints on Hindu Concepts of the Divine. Journal for the Scientific Study of Religion. https://doi.org/10.2307/1388144

Chapman, W. (2013). A heritage of ruins: The ancient sites of Southeast Asia and their conservation. In A Heritage of Ruins: The Ancient Sites of Southeast Asia and their Conservation.

https://doi.org/10.5860/choice.51-3918

Donder, I. K., Putu Andre Suhardiana, I., \& Ketut Sudarsana, I. (2020). Epistemological

Framework of Hindu Theology: A Study in Vedic Hermeneutic Perspective. Journal of Critical Reviews, 7(13), 311-319. https://doi.org/10.31838/jcr.07.13.53

Everitt, N. (2010). The Divine Attributes.

Philosophy Compass.

https://doi.org/10.1111/j.1747-

9991.2009.00264.x

Harriyadi, H. (2020). Pertimbangan Pemilihan Lokasi Kompleks Candi Dieng. AMERTA. https://doi.org/10.24832/amt.v37i2.123-138

Holmes, S. R. (2009). The Attributes of God. In The Oxford Handbook of Systematic Theology. https://doi.org/10.1093/oxfordhb/9780199245 765.003.0004
Kramrisch, S. (1954). The Art of India. The Paidon.

Kramrisch, S. (1976). The Hindu Temple. Motilal Banarsidass Publishers Private Limited.

Maulana, R. (2002). Siva Trisirah : Suatu Analisis Ikonografi.

Munandar, A. A. (2016). Kisah-kisah dan Kepercayaan Rakyat di Seputar Kepurbakalaan. Paradigma, Jurnal Kajian Budaya. https://doi.org/10.17510/paradigma.v2i1.15

Poerbatjaraka. (1992). Agastya di Nusantara. Yayasan Obor Indonesia.

Rao, G. (1914). Elements of Hindu Iconography. The Law Printing House.

Rao, G. (1968). Elements of Hindu Iconography I, II. Motilal Banarsidass.

Rosenkrantz, G., \& Wierenga, E. R. (1991). The Nature of God: An Inquiry into Divine Attributes. Philosophy and Phenomenological Research. https://doi.org/10.2307/2107902

Sedyawati, E. (1979). Laporan Penelitian Keterangan Ikonografis dari Sumber-Sumber Pustaka Jawa Kuno.

Sedyawati, E., Santiko, H., Djafar, H., Maulana, R., Wiwin, R., \& Ashari, C. (2013). Candi Indonesia : Seri Jawa: Vol. I (1st ed., Issue 1). Direktorat Pelestarian Cagar Budaya dan Permuseuman, Direktorat Jenderal Kebudayaan, Kementerian Pendidikan dan Kebudayaan. https://doi.org/10.1017/CBO9781107415324.0 04

Sharma, B. (1976). Iconography of Sadasiva. Abhinav Publication.

Soekmono, R. (1979). Pengantar Sejarah Kebudayaan Indonesia 1. Kanisius.

Sukatno, O. (2004). Dieng Poros Dunia. IRCiSoD. Sura, I. G. (2002). Agastya Parwa: teks dan terjemahan. Widya Dharma.

Surpi, N. K. (2019). Teologi Hindu di Kompleks Percandian Dieng Wonosobo Jawa Tengah.

Surpi, N. K. (2020). Śivagrha (Prambanan Temple) as an Archetype of Hindu Theology in 
Nusantara (An Endeavor to Discover Hindu Theological Knowledge through Ancient Temple Heritage). Analisa: Journal of Social Science and Religion, 5(01).

https://doi.org/10.18784/analisa.v5i1.1024

Surpi, N. K., Avalokitesvari, N. N. N., Ardana, I. K., Sukanta, I. K., \& Subrata, I. D. M. (2020). The divinity philosophy of vaiȘNava and its interpretation by the warga bhujangga waisnawa in Bali. International Journal of Advanced Science and Technology.
Titib, I. M. (2003). Teologi \& Simbol-Simbol

Dalam Agama Hindu. Paramita.

Wallace, W. L. (1978). An overview of elements in the scientific process. In J. Bynner \& K. M. Stribley (Eds.), Research Design The Logic of Social Inquiry. Routledge.

Wallace, W. L. (2017). The logic of science in sociology. The Logic of Science in Sociology. https://doi.org/10.4324/9781315132976

\section{Conflict of Interest}

Conflicts of Interest Statement

Manuseript's title. Interpretatioa of Symbols, Veneration And Diviae Attributs In Dieng Temple Complex, Central Java.

The authoes whose naenes are listed immodately below certify that they tave NO affiliations with or

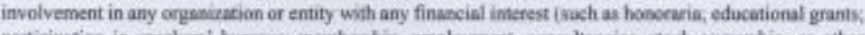
perticipation in speakers' bureaus; membership, employment, consultancies, stock owsenhip, of other Qquily interest, and expert testimony of patenl-licensing amangements) or non-financial interest (such as penonal er professional relationships, affiliations, ksowleder or beliefs) in the sabjest matter or materials discussed in this manuseript

Auttor Names

Author's name

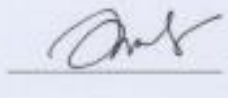

6. March 2021

IMade Gumi Santi Untan

I Ketut Sudaruna

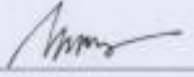

61" Mareh 2021

\section{Acknowledgements}

We want to thank all the researchers and archaeologists at the Yogyakarta Archeology Center for the vital information and permission to read at the Archaeological Center Library and Central Java Cultural Heritage Preservation research results. Equally, we also thank officers at the Dieng Kailasa museum, officers and curators at the Museum. We are also grateful to Prambanan and the curators and officers at the National Museum of Indonesia, Jakarta, for their assistance and willingness to provide several important information in this research. Thanks to Professor Dr. I Made Titib, Ph.D (Ida Pandita Mpu Acarya Jaya Daksa Wedananda) and I Ketut Donder, PhD, for their essential insights on theology. 
Author Contribution Statement

Category I-Conception and design: Ni Kadek Surpi; Ni Nyoman Ayu Nikki Avalokitesvari

Acquisition of Data: Ni Kadek Surpi; Ni Nyoman Ayu Nikki Avalokitesvari; I Made Gami Sandi Untara

Analysis and Interpretation of Data: Ni Kadek Surpi; Ni Nyoman Ayu Nikki Avalokitesvari; I Ketut Sudarsana
Category 2-Drafting the Article: Ni Kadek Surpi; Ni Nyoman Ayu Nikki Avalokitesvari; I Made Gami Sandi Untara

Revising it for Intellectual Content: I Ketut Sudarsana; Ni Kadek Surpi; Ni Nyoman Ayu Nikki Avalokitesvari

Category 3-Final approval of the completed Article: I Ketut Sudarsana; Ni Kadek Surpi; Ni Nyoman Ayu Nikki Avalokitesvari

Final approval of the version to be puclished: I Ketut Sudarsana; Ni Kadek Surpi 